\title{
KELINCAHAN REMAJA SMA HANG TUAH 4 SURABAYA
}

\author{
Anastasia Putu Martha Anggarani
}

STIKES Katolik St.Vincentius a Paulo Surabaya Program Studi Fisioterapi

\begin{abstract}
Background: The result of today's technological developments has stopped many people from natural exercise. Some of the jobs that exist, do not require us to move the body normally. If the jobs that exist do not make us move it will affect agility that will affect performance in carrying out activities. An description of agility is needed to identify the risk of decreased performance when doing activities in adolescents. Agility identification using an agility $t$ test. Agility $t$ test is a measuring instrument that has a reliability value of 0.98 , good for measuring agility. The aim of the study was to identify the agility of the Hang Tuah 4 high school students in Surabaya. Method: The type of this research is descriptive, which is to describe the agility of the Hang Tuah 4 Surabaya high school students. Result: The average value of respondents' agility score is 19.66. All respondents have the category of poor agility. This is because most of the respondents in this study did not carry out routine exercise activities (53.1\%). Sports activity is one of the factors that influence the improvement of agility. By carrying out routine sports activities, agility will be formed. Agility is a component that consists of aerobic endurance and muscle fitness, namely strength, muscle endurance and flexibility, reaction speed and motion, balance, power, and coordination. Interrelated components form an agility which is an important part of one's performance. Conclusion: To achieve this, the appropriate sports parameters are needed. One example is using the FIT principle, which includes: (1) Frequency of exercise 3 - 5 times a week, (2) Exercise intensity 60 -90\% of DNM, (3) Tempo / training duration 20 - 60 minutes in one practice time
\end{abstract}

Keywords: Agility, Teenagers

\section{PENDAHULUAN}

Kelincahan sering kali disamakan dengan koordinasi kemampuan gerakan, keterampilan, kemampuan menggerakkan otot-otot atau kecekatan. Kelincahan merupakan kualitas yang sangat komplek. Kelincahan ini mencakup interaksi kualitas-kualitas fisik yang lain (kecepatan reaksi, kecepatan, kekuatan, kelentukan, keterampilan gerak dan sebagainya), karena semua ini beraksi bersama. Kelincahan adalah kemampuan untuk merubah arah dan posisi tubuh atau bagian-bagiannya secara cepat (Ismayarti, 2008).

Kelincahan dipengaruhi oleh beberapa faktor diantarannya daya tahan aerobik dan kebugaran otot yang meliputi kekuatan, daya tahan otot, dan fleksibilitas. Komponen lain terdiri dari kecepatan reaksi dan gerak, keseimbangan, power dan koordinasi faktor. Hal-hal tersebut saling berkaitan membentuk suatu kelincahan yang merupakan bagian penting bagi semua orang dalam melakukan kegiatannya. Dengan kemampuan merubah arah dan 
posisi yang tinggi akan semakin lincah gerakan melakukan aktivitas (Nossek, 1982). Memang banyak hal yang perlu disadari bahwa akibat dari perkembangan teknologi dewasa ini, telah menghentikan banyak orang dari gerak badan alami. Sebagian pekerjaan-pekerjaan yang ada, tidak menuntut kita untuk menggerakkan badan dengan normal. Jika pekerjaanpekerjaan yang ada tidak membuat kita bergerak maka akan mempengaruhi kelincahan yang akan mempengaruhi performance dalam melakukan aktivitas. Gambaran kelincahan diperlukan guna mengidentifikasi risiko penurunan performance saat melakukan aktivitas pada remaja. Identifikasi kelincahan dengan menggunakan alat ukur agility $t$ test. Agility $t$ test merupakan alat ukur yang mempunyai nilai reliabilitas 0.98 , baik untuk mengukur kelincahan. Tujuan penelitihan ini adalah untuk mengetahui kelincahan siswa-siswi Hang Tuah 4 Surabaya

\section{METODE PENELITIAN}

Peneliti menggunakan desain penelitian yaitu observasional. Tempat penelitian ini dilakukan di SMA Hang Tuah 4 Surabaya. Sampel pada penelitian ini adalah sebanyak 32 remaja SMA yang bersedia menjadi sampel, berusia 16-18 tahun, dapat mengikuti instruksi, tidak mengalami cedera tungkai 1 tahun terakhir dan tidak mengalami nyeri pada tungkai atau sedang sakityang Sampel diambil dengan menggunakan teknik Proportional random sampling. Instrumen dalam penelitihan penelitihan ini adalah agility $t$ test. Lari dari titik start (bendera A), bersamaan dengan itu, waktu tempuh lari mulai diambil dengan menggunakan stopwatch. Lari sprint dari kerucut A menuju kerucut $B$ dan menyentuh dasar kerucut dengan menggunakan tangan kanan. Kemudian berlari menyamping menuju kerucut $\mathrm{C}$ dan menyentuh dasarnya dengan menggunakan tangan kiri, kemudian berlari menyamping menuju kerucut $\mathrm{D}$ dan menyentuh dasarnya dengan menggunakan tangan kanan. Setelah itu kembali ke kerucut B dan menyentuh dengan menggunakan tangan kiri dan berlari mundur ke kerucut A. Stopwatch dihentikan saat sampai di titik finish(bendera A) dan waktu lari dalam hitungan detik disinkronkan dengan tabel kategori nilai agility $t$ test. Saat berlari menyamping, tidak boleh menyilangkan kaki atau menyeret salah satu atau kedua kaki. Prosedur Scoring didasarkan pada waktu tempuh lari dari kerucut A kembali ke kerucut A. Hasil skor kelincahan dalam satuan detik dan kemudian dimasukkan ke dalam peringkat kelincahan. Tes dianggap gagal saat responden gagal menyentuh dasar kerucut atau menyilangkan satu kaki di depan atau menyeret.

Tabel 1. Kategori nilai kelincahan

\begin{tabular}{lll}
\hline Kategori & \multicolumn{1}{c}{$\begin{array}{c}\text { Laki-laki } \\
\text { (detik) }\end{array}$} & \multicolumn{1}{c}{$\begin{array}{c}\text { Perempuan } \\
\text { (detik) }\end{array}$} \\
\hline Excellent & $<9,5$ & $<10,5$ \\
Good & $9,5-10,5$ & $10,5-11,5$ \\
Average & $10,5-11,5$ & $11,5-12,5$ \\
Poor & $>11,5$ & $>12,5$ \\
\hline
\end{tabular}

\section{HASIL PENELITIAN}

Hasil karakteristik responden dapat dilihat pada tabel berikut :

Tabel 2. Karakteristik Responden Penelitian

\begin{tabular}{ccc}
\hline Variabel & Sub Grup & $\begin{array}{c}\text { Total } \mathbf{n}=\mathbf{3 2} \\
\text { Mean }(\boldsymbol{\%})\end{array}$ \\
\hline Usia (tahun) & & 16
\end{tabular}




$\begin{array}{lcc}\text { Jenis Kelamin } & \text { Laki-laki } & 18(56,2) \\ & \text { Perempuan } & 14(43,8) \\ \text { IMT } & & 21,8 \\ \begin{array}{l}\text { Nyeri/Pasca } \\ \text { cedera tungkai }\end{array} & \text { Ya } & 4(12,5) \\ & \text { Tidak } & 28(87,5) \\ \text { Aktivitas OR } & \text { Ya } & 15(46,9) \\ \text { Rutin } & & \\ & \text { Tidak } & 17(53,1)\end{array}$

Tabel tersebut menggambarkan informasi mengenai karakter responden penelitian. Data didapatkan rata-rata usia responden adalah 16 tahun. Responden laki-laki lebih banyak daripada perempuan yaitu $56,2 \%$. IMT rata-rata responden 21 yang berarti ideal. Responden yang mempunyai keluhan nyeri atau paska cedera tungkai sebanyak $36,1 \%$. Sebagian besar responden $(53,1 \%)$ tidak melakukan olahraga rutin.

Tabel 3. Distribusi Kelincahan

\begin{tabular}{lc}
\hline \multicolumn{1}{c}{ Variabel } & $\begin{array}{c}\text { Total } \mathbf{n}=\mathbf{3 2} \\
\text { Mean } \pm \text { SD/n }(\%)\end{array}$ \\
\hline Nilai kelincahan & $19,66 \pm 5,5$ \\
Kategori & Poor $(100 \%)$ \\
kelincahan & \\
\hline
\end{tabular}

Tabel 2 menunjukkan tentang karakteristik kelincahan responden. Sebagian responden memiliki nilai kelincahan yaitu 19,66 dengan arti dalam kategori poor

\section{PEMBAHASAN}

Berdasarkan penelitian yang dilakukan, maka peneliti akan membahas hasil yang telah didapatkan oleh peneliti mengenai gambaran kelincahan siswa siswi SMA Hang Tuah 4 Surabaya, dari 32 responden rata-rata nilai kelincahan responden 19,66 dengan arti berada dalam kategori poor memiliki.

Pada penelitian ini, jumlah subyek terbanyak terdapat pada segmen usia 16 tahun. Usia Kelincahan anak meningkat sampai kira-kira usia 12 tahun (memasuki pertumbuhan cepat). Selama periode tersebut (hingga 3 tahun setelahnya) kelincahan tidak meningkat, bahkan menurun. Oleh sebab itu, hal inilah yang menyebabkan kelincahan responden berada dalam kategori poor. Setelah masa pertumbuhan berlalu, kelincahan meningkat lagi secara mantap sampai anak mencapai maturitas dan setelah itu menurun kembali (Nugroho, 2005).

Sebagian besar responden penelitian ini tidak melakukan aktivitas olahraga yang rutin $(53,1 \%)$. Aktivitas olahraga merupakan salah satu faktor yang berpengaruh dalam peningkatan kelincahan. Aktivitas olahraga dapat diartikan sebagai suatu usaha untuk memperbaiki sistem organ alat-alat tubuh dan fungsinya dengan tujuan untuk mengoptimalkan penampilan atau kinerja individu. Tujuan aktivitas olahraga adalah meningkatkan fungsi potensial yang dimiliki individu dan mengembangkan kemampuan biomotoriknya sehingga mencapai standar tertentu (Nala, 2008). Dengan melakukan aktivitas olahraga yang rutin maka kelincahan akan terbentuk. Kelincahan merupakan bagian dasar dari semua macam olahraga maupun aktivitas yang memerlukan perubahan posisi badan secara cepat. Kelincahan merupakan suatu komponen yang terdiri dari daya tahan aerobik dan kebugaran otot yaitu kekuatan, daya tahan otot dan fleksibilitas, kecepatan reaksi dan gerak, keseimbangan, power, dan koordinasi. Komponen saling berkaitan membentuk suatu kelincahan yang merupakan bagian penting pada performance seseorang.

Untuk mencapai hal tersebut maka diperlukan parameter olahraga yang 
sesuai. Salah satu contoh adalah dengan menggunakan prinsip FIT, yang meliputi :(1) Frekuensi latihan $3-5$ kali dalam satu minggu, (2) Intensitas latihan $60-90$ $\%$ dari DNM, (3) Tempo / lama latihan 20 - 60 menit dalam satu kali latihan (Bompa, 2009).

Salah satu contoh aktivitas olahraga yang dapat meningkatkan kelincahan adalah senam aerobik. Seperti penelitian yang dilakukan David R.Hopkins dkk di American Alliance of Helth tahun 1999 yang memberikan perlakuan senam aerobik low impact pada 53 wanita selama 12 minggu dan setelah 12 minggu perlakuan, kelompok tersebut terdapat peningkatan komponen functional fitness salah satunya adalah kelincahan.

Penelitian lain di University of Miami Medical School pada tahun 1990 pada 24 anak dengan 12 anak pada kelompok control dan 12 anak pada kelompok perlakuan. Anak pada kelompok perlakuan diberi senam aerobik selama 30 menit selama 8 minggu. Setelah mendapat senam aerobik, kelompok perlakuan menunjukkan adanya perubahan yang signifikan yaitu peningkatan agility dan kebugaran fisik lain.

\section{KESIMPULAN DAN SARAN}

Kesimpulan dari penelitian ini adalah Responden penelitian ini mempunyai nilai kelincahan rata-rata 19,66 . Terdapat 32 orang $(100 \%)$ yang termasuk dalam kategori kelincahan poor.

Peneliti melihat adanya potensi untuk pengembangan hasil penelitian selanjutnya, sehingga diperlukan saran untuk tempat penelitian hendaknya memprogramkan siswa dan siswi SMA Hang Tuah 4 Surabaya untuk melakukan aktivitas olahraga terutama senam aerobic secara rutin dengan parameter $3-5$ kali dalam satu minggu dengan tempo senam $20-60$ menit

\section{DAFTAR RUJUKAN}

Arikunto. (2006). Prosedur penelitian Suatu pendekatan praktik. Jakarta: Rineka Cipta.

Bompa, T. (2009). Periodization Training for Sports: Theory and. Methodelogy of Training. Fifth Edition. United State of America: Human Kinetics.

Gunarsa. (2004). Psikologi Perkembangan Anak dan Remaja. Jakarta: Gunung Mulia.

Harsono. (1988). Coaching dan Aspekaspek Psikologis dalam Coaching. Bandung: Tambak Kusuma.

Hidayat, A. A. (2011). Metode Penelitian Kebidanan dan Teknik. Analisis Data. Jakarta: Salemba Medika.

Ismayarti. (2008). Peningkatan kelincahan Atlet melalui penggunaan metode kombinasi latihan sirkuit pliometrik dan berat badan. Jurnal Paedagogia , 11.

Kanginan, M. (2006). FISIKA untuk SMA kelas XI. Jakarta: Erlangga.

Lutan, R. (2000). Asas-asas Pendidikan Jasmani Pendekatan Pendidikan. Gerak di Sekolah Dasar. Jakarta: Direktorat Jenderal Olahraga.

Mappaompo. (2011). Kontribusi Koordinasi Mata-Kaki dan Kelincahan Terhadap Keterampilan Menggiring Bola Dalam Permainan Sepakbola Club Bilopa Kabupaten Sinjai. Jurnal ILARA , 96-101.

Nala. (2008). Denpasar: Yayasan Ilmu Faal Widhya Laksana. 
Nala. (2011). Prinsip Pelatihan Fisik Olahraga. Denpasar: Universitas Udayana.

Nossek, Y. (1982). Teori Umun Latihan. Lagos Institut Nasional Olahraga: Lagos Pan African Press LTD.

Nugroho, T. P. (2005). Hubungan Antara Kecepatan dan Kelincahan terhadap Ketrampilan Menggiring Bola dalam Sepak Bola pada Siswa Lembaga Pendidikan Sepakbola Atlas Binatama Semarang. Under Graduates thesis, Universitas Negeri Semarang .

Purwanto, N. (2006 ). Ilmu pendidikan Teoritis dan Praktis. Bandung: Remaja Rosda Karya.

Pyke. (1990). Training for sports and fitness. Melbourne Victoria: Macmillan Educational.

Queen, E. (2014, Februari 10). Fast and Slow Twitch Muscle Fibers. Does Muscle Type Determine Sports Ability? Retrieved April 19, 2018, from sportmedicine.com: http://sportsmedicine.about.com/o d/anatomyandphysiology/a/Muscl eFiberType.htm

Rudiyanto. (2012). Hubungan Berat Badan Tinggi Badan dan Panjang Tungkai dengan Kelincahan. Journal of Sport Sciences and Fitness Semarang .

Setiadi. (2007). Konsep dan Penulisan Riset Keperawatan. Yogyakarta: Graha Ilmu.

Sukadiyanto. (2005). Pengantar Teori Dan Melatih Fisik. Yogyakarta: FIK. Universitas Negeri Yogyakarta.

Widiastuti. (2015). Tes Dan Pengukuran Olahraga. Jakarta: Rajawali Press.
Womsiwor. (2014). Pelatihan Lari Sircuit Haluan Kiri Lebih Baik Dari Pada Haluan Kanan Untuk Meningkatkan Kelincahan Pemain Sepakbola Siswa SMK X Denpasar. Sport and Fitnes Journal , 10-17. 